\title{
LA VENGANZA DE EMMA BOVARY. LENGUA Y PAISAJE EN MATATE, AMOR DE ARIANA HARWICZ
}

Sobre Ariana Harwicz. Matate, amor. Buenos Aires, Mardulce. 2017. 160 pp.

Verónica Stedile Luna

UNLP

CONICET-IDICHS

"¿Qué es un hombre que muere? ¿Qué fue uno que no fue de su vida?", se pregunta la narradora de Matate, amor (Harwicz, 2017, p.96). "Justo" es la palabra que utiliza para introducir el párrafo siguiente señalando que escucha comentar Mrs. Dalloway por la radio. "Justo" porque en la lectura de ese encabalgamiento nos asalta un recuerdo, Clarisa Dalloway preguntándose "¿qué significaba para ella esa cosa que llamaba vida?" (Woolf, 2009, p.171). Enunciar esa coincidencia, como reversos del pensamiento, es también correr el riesgo de interpretar tal vez demasiado. Podríamos decir que mientras Mrs. Dalloway es una mujer de la aristocracia inglesa que se pregunta por la vida en la ligera asfixia que le causa la rutina social que sostiene, la protagonista de Matate, amor es una extranjera que se pregunta por la muerte y habla con fastidio una imagen de la clase media rural -"Mi marido me ve putear de lejos, me lee los labios y sonríe con un pucho detrás de la oreja, es un almacenero" (p.42)-, una mujer que habla del deseo con violencia. Pero en todo caso la presencia de Virginia Woolf anuncia en esta, la primera novela de Ariana Harwicz, reeditada en 2017 por Mardulce, la exigencia de una forma que habrá venido después: sacrificar una gramática que organiza el 
tiempo (y con ella los conectores, conjunciones, referencias deícticas) a favor de una imagen que avanza sin el apoyo de las estructuras.

Tal vez entonces sí podríamos pensar Matate, amor en una triple arista de sensibilidades: Woolf; un sonido del siglo XIX que marca el ritmo en algunas escenas, y una naturaleza bestial. A diferencia de La débil mental cuyo primer párrafo es un parlamento al borde de la escena, "No vengo de ningún lado. El mundo es una cueva, un corazón de piedra que aplasta, un vértigo plano. El mundo es una luna cortada a latigazos negros, a flechazos y escopetazos. Cuánto hay que cavar para dar con el desprecio, para hacer que mis días ardan" (Harwicz, 2016, p.7); el comienzo de Matate amor arrastra el sonido y el marco de un relato decimonónico, donde se acumulan afecciones contrapuestas: "Me recliné sobre la hierba entre árboles caídos y el sol que calienta la palma de mi mano me dio la impresión de llevar un cuchillo con el que iba a desangrarme de un corte ágil en la yugular" (Harwicz, 2017, p.7). Una primera oración que presenta lo imposible de un espacio rural donde una mujer se consume en su deseo. Desde esa primera línea se cifra el vínculo entre cuerpo y paisaje. En la pastura suele recortarse la figura de unas faldas coloridas, un cuerpo reposa o se agazapa para atacar. No hay contemplación (ni si quiera del cielo; el marido busca constelaciones con un telescopio, ella el vacío entre dos estrellas), no hay economía de la naturaleza, ni ocio. Solo deseo de adentrarse en la tierra, o perderse en los matorrales; "lo que me salva es el ojo dorado del ciervo, mirándome todavía. (...) Él es mi hombre. El hombre que sabe mirar mi tristeza infinita. Los otros son apenas hombre. De qué sirve ser uno de ellos si el idioma que hablan no alcanza" (p. 71). La pastura está siempre al borde de volverse sexuada y la animalidad, fantasía: “¿Cómo eyaculará un jabalí?" (p. 16). "Y cuando deseo soy una vaca con la cabeza atorada. Y 
si deseo soy un ciervo entrando al bosque como lo haría un novio a la iglesia" (p. 74). Como en Marosa di Giorgio, no hay metáfora; sin embargo, a diferencia de los personajes con muchos clítoris que podíamos encontrar en los jardines de la escritora uruguaya, en Matate, amor el límite es institucional: la familia. No hay metáfora que sostenga el desborde de la fantasía, pero entonces la vida como cultura del orden lo contiene: el marido llama, la suegra pasa a buscarla para dar un paseo, existen clínicas psiquiátricas, cumpleaños de amigos, un amante a pocas cuadras, cumpleaños infantiles.

Hay una doble extranjería: Harwicz escribe desde Francia, hace ya casi diez años, y escribe en español; sin embargo no ha sido traducida al francés hasta ahora. Esa extranjería es tal vez más notable en la lengua de su literatura que en sus personajes. Es una lengua de arrastre, como si al rastrillar juntara todo lo que hay: pastura, viejos cacharros, elementos de la economía más formal (sueldos, billetes, motos nuevas), imágenes diáfanas, imágenes darkis, refranes de una lengua vieja y gastada, onomatopeyas, giros de invención sofisticada y el recurso a frases hechas. Pero el lenguaje no se aligera, se satura de banalidad muchas veces, de lugares comunes ("un hombre como yo" (p. 31), "entre todos no hacen uno" (p. 53), "linda sorpresita para su tribu de hijos" (p. 8), "qué día de humedad" (p. 10), "me hacés daño" (p. 56)) pero se retiran de la condescendencia comunicativa: "en el campo uno se pasa la vida asesinando" (41), "salió galopando" (p.39), "agarrá un cuchillo y cortate la boca" (p.39). Ritmo de contrapuntos que alternan lo patético y lo extraño, lo patético y lo que quisiera ser sublime; es, muchas veces, un intervalo entre lo patético y lo patético que se exhibe como interrupción de su propia fealdad:

Afuera mi marido larga un chorrazo color mate, puedo ver las gotas calientes y amarillentas sobre la chapa del garaje 
dibujando una cascada. Se da vuelta, me sonríe con las manos en el sexo laxo y llovedizo y apaga el pucho que tiene en la boca con su cascada de pis. ¿Miramos las estrellas? Nunca supe cómo explicarle que no me interesan las estrellas (pp.11-12).

Una pregunta que surge al leer Matate amor, también Precozy La débil mental es cómo se sostiene una voz sin cortes, casi, cuando esta es ella misma voz siempre cortada. Hay un exceso en los personajes, hay des-sujeción permanente de la gramática, y a la vez la ruta del héroe, la heroína, diríamos, es clarísima, tradicional. Leemos dos movimientos, como si con una mano se sostuviera a rienda firme el relato, las partes de la ficción, mientras con la otra se borran los pasos, y la lengua se suelta de esa rienda. Firmeza y de-sujeción al mismo tiempo; dirección y corte, como contrapuntos. La historia podría contarse en no más de tres o cuatro oraciones: una mujer en puerperio vive en el campo con su marido y es infeliz; tiene un amante, no la satisface; piensa en coger, pero no quiere hacerlo; enloquece al marido, pero se ignoran; no odia a sus suegros, la apenan; se extraña de su bebé, donde confluyen sentimientos encontrados ("Hay que tirarlo al desierto, que lo devoren las bestias. Al deseo" (p. 90)); los celos la ciegan, se corta, se recupera, sugiere casarse, lo hacen, en la noche de bodas algo sucede, la internan, se recupera y sale, algo se arruina, o tal vez siempre estuvo arruinado. Siguiendo la escena melodramática de los celos, en la cual nuestra protagonista dice, "me hacés daño", podríamos tirar del hilo del tono y enunciar Emma Bovary ha vuelto para vengarse.

Ariana Harwicz parece reescribir, para su protagonista -que carece de nombre-, tres elementos relacionales claves en Madame Bovary: el cuerpo, la comida y el paisaje; se trata de espacios y materialidades donde se cifra el desenlace narrativo 
como desastre. Porque si hay algo a lo cual la gramática de cortes de Harwicz no renuncia, eso es a la sucesión de acciones que solo pueden resolverse hacia adelante. Emma Bovary lo intenta todo para disponer su cuerpo a la afirmación del deseo. Recordaremos cómo se nos presenta por primera vez a los lectores y a Charles: "se puso a coser, se pinchó varias veces los dedos y cada vez que le ocurría, se los llevaba a la boca y se los chupaba" (Flaubert, 2007, p.83). Casi inmediatamente después, en la despedida, Emma deja caer su pañuelo mientras levanta una maleta, quedando al descubierto un hombro por accidente. Esa escena de seducción corporal varía y retorna a lo largo de la novela como evidencia del desprecio (Charles no es ya quien mira a una jovencita llevarse los dedos a la boca, sino un marido que se duerme a la mesa, engorda) o bien como irónica nostalgia de algo que no se distingue entre lo vivido y lo inventado:

Después de intentar de ese modo arrancarle chispas a su corazón sin lograr que brotara ni una, incapaz, por otra parte, de comprender lo que ella no sentía, ni de creer en nada que no se manifestara bajo un aspecto convencional, terminó por convencerse fácilmente de que la pasión de Charles no tenía nada de exorbitante. Que sus efusiones amorosas se tornaron rutinarias; se besaban a ciertas horas. Era una costumbre como tantas otras; como un postre previsto de antemano después de la monotonía de la cena (2007, p.113).

Matate, amor comienza en la ruina: "somos parte de esas parejas que mecanizan la palabra "amor" hasta cuando se detestan; amor, no quiero volverte a ver" (2017, p.9); si Emma contrasta el hastío con la lectura (leer no salva del aburrimiento, pero alimenta la posibilidad de que algo suceda), la mujer extranjera, "letrada y graduada universitaria" (p. 8) que 
habita la ruralidad de una Francia que se parece poco a las luces de la metrópoli, dice "yo soy una mujer que se dejó estar y tiene caries y ya no lee. Leé idiota, me digo, leéte una frase de corrido. Acá estamos los tres juntos para una foto familiar" (p. 9). Si el paisaje, la rutina, la lectura, la familia, son enclaves de reenvío entre esas escrituras, no lo son en virtud de su coincidencia, sino de un fuerza fantasmática que en Matate, amor podría operar como venganza de una Emma que intentó dar con la realización del deseo en los ofrecimientos de la cultura, pero encontró entonces el diferimiento permanente de aquello que solo pide ser alimentado. La protagonista que Harwicz pone allí, entre hombres que "preparan el invierno como bestias", que comen sanwichitos en Navidad, entre granjas y corrales, "este ambiente familiar de pertrechos, bosta, engorderos y perros de caza" (p. 32), esa mujer que puede atravesar con su propio cuerpo una puerta de vidrio para huir a los pastizales, experimenta, desde el inicio, el tormento de anhelar la felicidad de una vida normal, y la constatación de que el deseo puede adoptar las formas más inquietantes - que provienen, las más de las veces de la misma naturaleza - y ser insuficiente en cada instancia. La venganza es sobre el anhelo como motor, es la destrucción de una creencia según la cual los imaginarios culturales saturan lo que un cuerpo exige.

Dos pasajes de Madame Bovary donde el espacio, como paisaje o como encierro, es la inestabilidad entre la calma o el exceso:

No le gustaba el mar sino por sus tempestades y el verdor de los campos tan solo si aparecía salpicado entre ruinas. Necesitaba extraer de las cosas una especie de provecho personal y rechazaba como inútil todo aquello que no contribuía al consumo inmediato de su corazón, por cuanto, de temperamento más sentimental que artístico, buscaba emociones y no paisajes (2007, p.105). 
En su deseo se confundían las sensualidades del lujo con las alegrías del corazón, la elegancia de las costumbres con las delicadezas del sentimiento. ¿Acaso no precisaba el amor, como las plantas tropicales, de unos adecuados terrenos, de una temperatura especial? (2007, p.131)

Nada de eso puede ya suscitarse en Matate, amor, porque el paisaje se destruye como horizonte de los imaginarios posibles para convertirse en naturaleza, en tierra, matorral, "árboles como tigres alzados" (p.154), orgía de animales, "sé que cuando abra el ventanal voy a ser un cisne negro, y cuando empiece a gritarme voy a ser un pato castrado". Es, finalmente la tierra, imagen que te envenena, como los ojos de un búho, como los ojos del ciervo. Reparemos si no, en las veces que el vidrio que separa la casa del exterior es roto, atravesado, astillado, lo que pasa por él. Una casa de vidrio, como la falsa transparencia y la materia peligrosa de ser derribada, es una forma de vengar a la Emma Bovary que se perdió entre los libros y el veneno. Porque ahora el campo es bestial y no solo aburrido, la vida en Matate, amor puede salir fortalecida, más soberana. 